\title{
Faculty Perceptions of Plagiarism: Insight for Librarians' Information Literacy Programs
}

\author{
Russell Michalak, Monica Rysavy, Kevin Hunt, \\ Bernice Smith, and Joel Worden
}

\begin{abstract}
Using a survey modified from The Plagiarism Handbook, ${ }^{1}$ the research team surveyed all undergraduate and graduate faculty $(n=79)$ teaching during the fall 2016 semester at a small private college in the United States. With a final survey response rate of 59.5 percent $(n=47)$, the researchers learned that, while the faculty's definitions of plagiarism fluctuated, overall faculty definitions paralleled the official definition of plagiarism at this institution. Furthermore, the researchers learned that the vast majority of faculty, 74 percent $(n=35)$, do not currently invite library staff into their classrooms to teach students how to avoid plagiarism. Given this finding, this study indicates that there was an opportunity for librarians to collaborate with faculty to develop new information literacy and plagiarism deterrent resources. These were intended to support faculty teaching and to additionally market the existing online information literacy training modules, previously developed as part of the authors' Information Literacy Assessment (ILA) program. ${ }^{2}$
\end{abstract}

\section{Introduction}

As part of an effort to support this institution's faculty in deterring student plagiarism and to expand on the researchers' information literacy training program (Information Literacy Assessment (ILA) and Students' Perceptions of Information Literacy-Questionnaire (SPIL-Q) instruments) at the institution where this research was conducted, the research team collected and analyzed faculty's perceptions of plagiarism. ${ }^{3}$ The purpose of this study was to gauge faculty perceptions of student plagiarism and to identify how library information literacy resources were current used and underused. With this in mind, this study was guided by two research questions:

RQ1: How do faculty define plagiarism?

RQ2: How do faculty attempt to deter student plagiarism?

RQ3: To what extent are library information literacy resources used to combat plagiarism?

Russell Michalak is Director of the Library E Learning Center, e-mail: michalr@gbc.edu; Monica Rysavy is Director of Institutional Research E Training, e-mail: rysavym@gbc.edu; Kevin Hunt is Assistant Professor, English E Humanities, e-mail: huntk@gbc.edu; and Joel Worden is Associate Professor, English, e-mail:wordenj@gbc.edu, all at Goldey-Beacom College. Bernice Smith is an independent researcher. (C2018 Russell Michalak, Monica Rysavy, Kevin Hunt, Joel Worden, and Bernice Smith. 
The team adapted an instrument based on The Plagiarism Handbook ${ }^{4}$ that assessed faculty's views of plagiaristic behaviors, collected faculty's definitions of plagiarism, surveyed faculty's uses of anti-plagiarism materials, and gauged faculty's use of the college's library resources (both databases and library instruction) in their classes. The results revealed variations in faculty members' $(n=47)$ definitions of plagiarism and in their approaches to educating students about plagiarism, from discussing its definition in class, to providing written material about it, to inviting library staff into classrooms to discuss methods for avoiding it. The results suggested a need for more studies to examine faculty members' definitions of plagiarism and revealed an opportunity for librarians to collaborate with faculty to play an increased role in providing professional development to faculty about plagiarism.

\section{Literature Review}

Librarians have a unique role in universities and colleges to combat student plagiarism as they lead efforts to introduce information literacy programming into the curriculum. On the one hand, as Lampert explained, some educators perceived information literacy instruction as duplicating the work of writing composition programs, and "this similarity is vital to understanding why anti-plagiarism instruction remains on the fringe of instructional curricula with both of these emerging fields and in academia as a whole." ${ }^{5}$ However, Hall asserted that, for a writing program to be successful, it required:

Activities that involve the library staff in training students not just to find sources, but to evaluate them for appropriateness for a given project, and to use them effectively and honestly in their own programs. Information literacy must be a core goal of all contemporary universities, and anti-plagiarism efforts need to be a key component of any such initiative. ${ }^{6}$

In addition, Lampert posited librarians “...will also need to focus on emphasizing the critical thinking aspects involved in deciding when and how to cite information" in the classroom. ${ }^{7}$

Moreover, Sciammarella pointed out that "[a] knowledge of the research process itself and the so called 'rules of engagement' (documenting this process) needs to be explained and reinforced" by librarians. She further remarked "a goal of these classes [information literacy instruction] is to introduce research concepts for lifelong learning. The mechanism of research may change (for example, computer interfaces), but the need to document resources remains constant." 8

A growing number of librarians believe they are responsible for plagiarism prevention instruction. In 2010, Gibson and Chester-Fangman found that 87 percent of librarians $(n=530)$ felt they had a role in teaching plagiarism prevention. In this study, the researchers asserted, "Librarians support the delivery of plagiarism prevention instruction through workshops, one-shot library instruction sessions, tutorials, Web pages and handouts. ${ }^{\prime 9}$ Moreover, since the 1980s, librarians have collaborated with faculty to teach information literacy skills to students. ${ }^{10}$ Strittmatter and Bratton pointed out that there are many institutions including Boston College, San Diego State University, and Oakland University “... where librarians collaborate with faculty and staff from academic support centers to develop a broadly disseminated plagiarism prevention curriculum." ${ }^{\prime 11}$ Amsberry pointed out that it is librarians' responsibility to collaborate "with faculty to improve students' understanding of appropriate uses of textual sources." 12

As part of their collaborative efforts with faculty to improve teaching to deter plagiarism and enhance information literacy, librarians have assessed students' informa- 
tion literacy skills. ${ }^{13}$ In addition, librarians have worked with instructional designers to develop modules with computer-assisted instruction. ${ }^{14}$ As part of the development of one such computer-assisted program, Michalak and Rysavy were tasked by their institution to determine a baseline for the graduate students' $(n=172)$ computerassessed Information Literacy Assessment (ILA) scores. In their study, it became clear that there was a disconnect between students' actual ability to cite sources, as evidenced by their ILA scores, and their perceived ability to cite sources, as indicated by their Students Perceptions Information Literacy-Questionnaire (SPIL-Q) scores. In general, students believed they had an understanding of how to cite sources, but they did not satisfactorily demonstrate this knowledge. The discrepancy between students' performance and their perception raised questions about the information literacy and plagiarism instruction students were receiving in their classes and whether there were variations in the information and approaches they were receiving from various faculty. Therefore, the research team surveyed faculty on their perceptions of plagiarism to determine faculty perceptions of plagiarism, including how librarians could more fully understand these perceptions to assist faculty in teaching students not to plagiarize. ${ }^{15}$ To more fully understand factors that might inform faculty perceptions, the research team reviewed literature on the history of plagiarism through its definition.

With librarians increasingly collaborating with faculty on information literacy and plagiarism-deterrence programs, a common presumption is that librarians and faculty share uniform definitions and common understandings of plagiarism. However, a review of the history of plagiarism revealed its contentious nature. Societies that adhere to Anglophone conventions have defined the concept of plagiarism in many different ways for centuries. According to Angélil-Carter, "The concept of plagiarism did not exist until the Enlightenment, and is bound up with notions of copyright."16 Mazzeo indicated that this concept has evolved so that "in early nineteenth-century Britain, there was, in general, a distinction between two forms of plagiarism": "culpable" plagiarism and "poetical" plagiarism. ${ }^{17} \mathrm{He}$ argued "only culpable plagiarism represented a moral indictment of an author, and it was almost impossible to demonstrate conclusively during the period." ${ }^{18} \mathrm{He}$ also asserted that many prominent authors during the Romantic period allegedly plagiarized "ranging from Wordsworth and Coleridge to Byron, Clare, and Shelley."19

According to Simmons, during the late nineteenth century in the United States, student plagiarism became pervasive and a growing concern at particular larger higher education institutions. She stated in her essay about the origin of student plagiarism: "With the requirement to write papers came student plagiarism." ${ }^{20}$ She further articulated that "...by the end of the nineteenth century, two discourses about plagiarism and cheating were emerging: the official discourse of professors and textbooks, and unofficial discourse of students, from literary magazines and college novels." ${ }^{21}$

To this day, there continues to be an inconsistent definition of plagiarism within the Western academy. In 2011, Bennett, Behrendt, and Boothby pointed out that "historically, academicians have used phrases to refer to plagiarism including ethical errors, deceitful behavior, and student dishonesty." 22 Pincus and Schmelkin pointed out "one of the main issues that emerges from the literature relates to inconsistencies in the definition of academically dishonest behaviors and the lack of consensus and general understanding of academic dishonesty among the members of the campus community." ${ }^{23}$ Bennett et al. concurred that "there are numerous forms of plagiarism, and configuring a specific definition has been a challenge." ${ }^{24}$ Angélil-Carter argued that "the concept of plagiarism itself is constructed and relative, and is becoming increasingly problematic with new understandings of discourse and texts" and, therefore, it is understandable how faculty's perceptions of the definition of plagiarism and plagiaristic behaviors fluctuate. ${ }^{25}$ 
The difficulty in defining plagiarism could be attributed to the multiple ways that plagiarism has been categorized in the literature. Park enumerated four common forms of student plagiarism at academic institutions from the literature he explored: ${ }^{26}$

1. Stealing material from another source and passing it off as their own.

a. buying a paper from a research service, essay bank or term paper mill (either pre-written or specially written),

b. copying a whole paper from a source text without proper acknowledgement,

c. submitting another student's work, with or without that student's knowledge (e.g. by copying a computer disk).

2. Submitting a paper written by someone else (e.g. a peer or relative) and passing it off as their own.

3. Copying sections of material from one or more source texts, supplying proper documentation (including the full reference) but leaving out quotation marks, thus giving the impression that the material has been paraphrased rather than directly quoted.

4. Paraphrasing material from one or more source texts without supplying appropriate documentation. ${ }^{27}$

Carroll offered yet another definition of plagiarism, stating that plagiarism is "passing off someone else's work, whether intentionally or unintentionally, as your own for your own benefit." 28

Pecorari's study demonstrated that plagiarism could be categorized in two other ways: "Textual plagiarism - that is, language and ideas repeated from a source without (sufficient) attribution" and "prototypical cases of plagiarism: the intention to deceive. ${ }^{29}$ She expressed that "anecdotal accounts of such unintentional, non-prototypical plagiarism abound." 30

In addition to the definition of plagiarism fluctuating for the last three centuries, academic librarians Marcus and Beck pointed out that "the prevalence of cheating [plagiarism] and its definition have changed." ${ }^{31}$ One method of attempting to more accurately identify students' definitions of plagiarism has been for researchers to conduct survey research on this concept. Bower's 1964 study was a seminal work. His survey of 99 schools $(n=5,000)$ found that 75 percent of students admitted to participating in some form of academic dishonesty..$^{32}$ McCabe, Trevino, and Butterfield conducted a follow-up study in 2001 using the same methodology Bower used. Their study produced similar results to Bower's 1964 study. They pointed out that it was possible that an increase in offenses was not recognized in their follow-up study using Bower's 1964 methodology because of the potential "...changing definition among students of what constitutes plagiarism," ${ }^{\prime 3}$ and added that comparable results might have been found because the concepts analyzed in Bower's 1964 study "do not appear to be considered plagiarism by many students today." 34

In 2011, Evans-Tokaryk emphasized "many faculty members are probably unaware of the fact that the concept of plagiarism is in flux" and that there is an "absence of a coherent, stable definition of plagiarism itself." 35 In fact, Roig's 2001 study reported that approximately 50 percent of instructors "did not rate a paragraph as plagiarized when it contained at least one sentence copied verbatim from the original source." 36

In reviewing historical attempts to define plagiarism, Marsh echoed the findings of another scholar ${ }^{37}$ that a single, stable definition remains elusive, stating that "definitions of plagiarism and their related injunctions - in academia in particular - often shift in accordance with cultural, professional, and disciplinary assumptions and prejudices." 38 


\section{Challenges of Teaching How to Avoid Plagiarism}

In addition to revealing the problematic nature of defining plagiarism, a review of the literature revealed how inconsistencies in defining plagiarism have led to difficulty teaching students how to avoid plagiarizing. Authors such as Bennett et al. and Thomas commented that effectively educating students about academic misconduct and other forms of plagiarism in the university setting requires using an explicit definition. ${ }^{39}$

One source of confusion could be instructors' tendency to engage in pedagogical activities that involve what Foucault described as remixing others' words without using formal citation techniques. In an interview with Foucault regarding how he used other authors' works to support his own research, he stated:

But there is also a sort of game that I play with this. I often quote concepts, texts and phrases from Marx, but without feeling obliged to add the authenticating label of a footnote with a laudatory phrase to accompany the quotation. As long as one does that, one is regarded as someone who knows and reveres Marx, and will be suitably honoured in the so-called Marxist journals. But I quote Marx without saying so, without quotation marks, and because people are incapable of recognising Marx's texts I am thought to be someone who doesn't quote Marx. When a physicist writes a work of physics, does he feel it necessary to quote Newton and Einstein? He uses them, but he doesn't need the quotation marks, the footnote and the eulogistic comment to prove how completely he is being faithful to the master's thought. ${ }^{40}$

Foucault's "game" of tacitly acknowledging, but not officially citing sources parallels an issue recognized by other scholars: ${ }^{41}$ The challenge that the "intertextual" nature of writing presents to notions of originality and authorship, and by extension, the challenge it presents to teaching source citation to students. Intertextuality is a term that Kristeva created based in part on Bakhtin's philosophy of language that Holquist translated as heteroglossia, the web of relationships that exist in words and texts. According to Bakhtin, "The word in language is half someone else's." ${ }^{42}$ Though referring to language use in general, Bakhtin's philosophy of language, and the ensuing idea of intertextuality, frequently is used to express the idea that all texts derive meaning(s) from connections to other texts. For example, in her discussion of academic norms of citation, Blum noted that "all speech-including writing-draws in some way from other texts and speakers. This interdependence of words and ideas on prior sources is what we called 'intertextuality.'" 43

Blum further identified another source of confusion in teaching about source use: students use informal citation methods in their everyday use of texts, but these methods differ from academic requirements. Blum contended that, in their everyday cultural practices, students are fully engaged in a world of texts - a media environment in which they both consume and create a variety of texts-e-mail messages, blog posts, text messages - in ways that both rely on and establish connections between texts that "show verbal sophistication, memory, and sensitivity to context and appropriateness." ${ }^{44}$ In short, Blum pointed out students informally engage in the sort of source use that is required in academic writing. The difference is that students do not use the formal source citation systems that require them to "set up boundaries around each little piece of text, trace its origin, and document its source." ${ }^{45}$ However, "[s]tudent engagement in intertextual activity is of a different nature and different purpose from the intertextuality demanded by academia." 46

The challenge, advanced by Blum, that multiple and conflicting writing situations and genres present to writing instructors was echoed by Bloch, who stated: 
Plagiarism is similarly a problem of language. After all, these rules that govern plagiarism, like any set rules, are never monolithic or static. They can vary across different genres and different writing contexts, but most importantly, the more complex the rule, the more it needs to be taught so that everyone can play on a level playing field. This perspective can help both researchers and teachers develop a framework for discussing plagiarism and developing pedagogies for teaching about plagiarism that helps our L2 students understand its subtleties and contradictions, as well as the reason why the rules exist in the first place, in the same way they learn about any other aspect of literacy. ${ }^{47}$

In summary, a review of literature on the history of plagiarism, its definitions, and instruction on how to avoid it revealed a lack of consensus over its definition. In addition, it revealed difficulties in teaching its avoidance due to discrepancies between tacit, informal, intertextual uses of texts in instructors' pedagogical methods, and due to discrepancies between students' informal uses of texts and the formal requirements of academic citations. Given the discrepancies in definitions and pedagogical practices, as well as the discrepancies the research team previously identified between students' perceptions of their ability to properly cite sources and their actual ability to do so, the research team sought to survey faculty perceptions of plagiarism as a starting point in facilitating collaboration between librarians and faculty in developing an institutional program for preventing plagiarism.

\section{Methodology}

The research team built upon the research conducted by Marcus and Beck on faculty perceptions of plagiarism at a community college whose objective was "to see if the faculty has a uniform understanding of plagiarism and if that view is in keeping with the QCC Academic Integrity Plan." ${ }^{48}$ The research team used a survey from The Plagiarism Handbook..$^{49}$ The team modified that survey and developed Faculty Perceptions of Student Plagiarism (FPSP) instrument (see appendix A), which was vetted by an English faculty member and upper-level undergraduate students. The team wanted to identify faculty's views of plagiaristic behaviors with the purpose of developing related training programs that leverage the college's existing information literacy program. Furthermore, the college's institutional review board (IRB) reviewed this study, including details for maintaining the anonymity of respondents, and granted approval for this study to take place.

When analyzing the qualitative comments made by faculty codes identified were a mixture of in vivo codes as well as codes the researchers felt appropriately described the comments. After working independently, the authors met in several joint working sessions to discuss codes identified and discuss themes that emerged from the students' comments. ${ }^{50}$

\section{Survey Population and Administration}

Participants in this investigation were undergraduate and graduate faculty in a small private college in the United States. All full-time and adjunct faculty who taught during the fall 2016 semester $(n=79)$ were invited to participate in this study, which the researchers distributed using the online survey tool Qualtrics.

An initial e-mail was sent to faculty in August 2016, with two follow-up reminder e-mails sent to individuals who had surveys in progress or had not started the survey. The designated survey open period was August 17 through September 18, 2016. After the research team removed submissions that did not adhere to the participation criteria (that is to say, those who did not consent to permit the use of their unidentifiable responses 


\begin{tabular}{|l|c|c|c|c|}
\hline \multicolumn{5}{|c|}{ TABLE 1 } \\
Survey Respondents by Employment Status by Gender \\
\hline & \multicolumn{2}{|c|}{ Female Faculty } & \multicolumn{3}{c|}{ Male Faculty } \\
\hline Employment Status & $\mathrm{n}$ & $\%$ & $\mathrm{n}$ & $\%$ \\
\hline Full-time Faculty & 7 & $14.89 \%$ & 7 & $14.89 \%$ \\
\hline Adjunct Faculty & 6 & $12.77 \%$ & 27 & $57.45 \%$ \\
\hline Total & 13 & $27.66 \%$ & 34 & $72.34 \%$ \\
\hline
\end{tabular}

in articles, presentations, or public forums and incomplete surveys and one incomplete survey), 47 valid responses remained. This provided a final survey response rate of 59.5 percent. Table 1 illustrates faculty employment status (full-time or adjunct) by gender.

Of the 47 valid responses, 14 participants identified as full-time faculty members (50\% male and $50 \%$ female) and 33 participants identified as adjunct faculty members $(81.8 \%$ male and $18.2 \%$ female). Of the 79 faculty members teaching at the time of this study, 25 faculty members (31.65\%) identified as female and 54 faculty members identified as male $(68.35 \%)$. Faculty were asked how many years of teaching experience they had at the college level from a list of four choices: less than one year, one to five years, six to ten years, or more than ten years. Survey results revealed (as illustrated in table 2 ) that the majority of full-time faculty respondents $(78.6 \% ; n=11)$ have more than 10 years of teaching experience. The majority of adjunct faculty respondents reported having $1-5$ years of teaching experience $(35.3 \% ; n=12)$. This was closely followed by the number of respondents who indicated that they had more than 10 years of teaching experience $(29.4 \% ; \mathrm{n}=10)$.

\begin{tabular}{|c|c|c|c|c|c|c|c|c|}
\hline \multicolumn{9}{|c|}{$\begin{array}{c}\text { TABLE } 2 \\
\text { Survey Respondents by Employment Status by Years of Experience }\end{array}$} \\
\hline & \multicolumn{2}{|c|}{$<1$ Year } & \multicolumn{2}{|c|}{$1-5$ years } & \multicolumn{2}{|c|}{ 6-10 Years } & \multicolumn{2}{|c|}{$>10$ Years } \\
\hline Employment Status & $\mathrm{n}$ & $\%$ & $\mathrm{n}$ & $\%$ & $\mathrm{n}$ & $\%$ & $\mathrm{n}$ & $\%$ \\
\hline Full-time Faculty & 0 & $0.00 \%$ & 1 & $2.13 \%$ & 2 & $4.26 \%$ & 11 & $23.40 \%$ \\
\hline Adjunct Faculty & 3 & $6.38 \%$ & 11 & $23.40 \%$ & 9 & $19.15 \%$ & 10 & $21.28 \%$ \\
\hline Total & 3 & $6.38 \%$ & 12 & $25.53 \%$ & 11 & $23.40 \%$ & 21 & $44.68 \%$ \\
\hline
\end{tabular}

The college's courses are categorized into two departments: Arts \& Sciences and Business. For the purposes of this study, faculty who responded to the survey were categorized as primarily "Business" instructors or "Arts" instructors based upon the majority of courses they were scheduled to teach in fall 2016 and spring 2017. Survey results revealed (as illustrated in table 3 ) that the majority of full-time faculty respondents

TABLE 3

Survey Respondents by Employment Status by Academic Department

\begin{tabular}{|l|c|c|c|c|}
\hline & \multicolumn{2}{|c|}{ Arts } & \multicolumn{2}{c|}{ Business } \\
\hline Employment Status & $\mathrm{n}$ & $\%$ & $\mathrm{n}$ & $\%$ \\
\hline Full-time Faculty & 4 & $8.51 \%$ & 10 & $21.28 \%$ \\
\hline Adjunct Faculty & 12 & $25.53 \%$ & 21 & $44.68 \%$ \\
\hline Total & 16 & $34.04 \%$ & 31 & $65.96 \%$ \\
\hline
\end{tabular}


were teaching Business-categorized courses $(71.4 \% ; \mathrm{n}=10)$ and the majority of adjunct faculty members were teaching Business-categorized courses as well $(63.6 \% ; n=21)$.

Faculty who responded to the survey were also categorized as being undergraduate (UG faculty) or graduate (GR faculty) faculty for the purposes of this study. This categorization was based upon what courses they were scheduled to teach during the fall 2016 and spring 2017 semesters. Faculty who taught 60 percent or more of their classes in a given category (UG or GR) were classified as UG or GR faculty. Survey results revealed (as illustrated in table 4 ) that the majority of full-time faculty respondents were mainly teaching undergraduate courses $(57.1 \% ; \mathrm{n}=8)$ and the majority of adjunct faculty members were teaching undergraduate courses $(66.7 \% ; n=22)$.

\begin{tabular}{|l|c|c|c|c|}
\hline \multicolumn{5}{|c|}{ TABLE 4 } \\
Survey Respondents by Employment Status by Courses Primarily Taught \\
\hline & \multicolumn{2}{|c|}{ UG } & \multicolumn{3}{c|}{ GR } \\
\hline Employment Status & $\mathrm{n}$ & $\%$ & $\mathrm{n}$ & $\%$ \\
\hline Full-time Faculty & 8 & $57.1 \%$ & 6 & $42.9 \%$ \\
\hline Adjunct Faculty & 22 & $66.7 \%$ & 11 & $33.3 \%$ \\
\hline Total & 30 & $63.8 \%$ & 17 & $36.2 \%$ \\
\hline
\end{tabular}

\section{Results}

\section{Defining Plagiarism}

RQ1: How do faculty define plagiarism?

When prompted to provide their own definitions or descriptions of plagiarism, the instructors provided responses that reflect the inconsistencies and complications that plagiarism scholars have noted. Generally, the descriptions or definitions the respondents provided were structured in a common fashion (such as "Using someone else's work as your own"). In this structure, a verbal descriptor of the act of plagiarism (typically a gerund, such as "using," "copying," "taking," and the like), was followed by a descriptor of the material or object appropriated by the plagiarist ("words," "ideas," "work," and so on), and in some cases was then followed by a statement indicating the need to credit the original source (such as "without acknowledging the source"). Some definitions or descriptions contained other information or qualifications.

The majority of definitions specifically included the verbal expression of "using [materials]" or "the use of [materials]" to describe the act of plagiarism. However, many of the definitions used verbal expressions that suggested a greater degree of negativity than merely "using," or sometimes used them in combination with the term "using"; the other terms included "copying," "taking," "claiming," and "passing off." Several definitions contained verbal expressions that explicitly conveyed misconduct or criminality: "cheating," and "stealing."

Roughly half of the definitions or descriptions included a clause specifically indicating that plagiarism involves a lack of citation or acknowledgment (for instance, "turning in work that is not [his/her] own without attributing and acknowledging the original source of that work"; "using a source without acknowledgement (attribution)"; and "submittin[g] [sic] a written assignment or oral presentation which the student took all or some from another source without attribution"). The inclusion of the citation or acknowledgement comment may suggest a lack of differentiation between ignorance of citation practices and the dissembling involved in passing off someone else's work as one's own. However, some of the respondents did emphasize that plagiarism should be defined as "knowingly" using source material without citing it (examples: "knowingly copying without giving 
credit to the source"; "active intent to use the words, opinions and other written work [...] without attributing such to the original author"; and "knowingly using someone else's work and not applying the appropriate reference to that work"). One respondent emphasized the importance of considering the intent of the student: "I believe the term [plagiarism] should require fraud or GROSS negligence. Other negligence (not GROSS) should not be viewed as plagiarism but instead is simply part of the learning process which can and should be corrected and counseled and monitored" [original emphasis]. Alternatively, another respondent expressly ignored intentionality: "Ignorant or purposeful failure to credit another's work or one's previous work as such in one's own work."

Another variation in the definitions or descriptions involved the way in which the respondents described the object appropriated by the plagiarist. A majority of respondents used the word "work" to denote the material or object appropriated by the plagiarist (such as "using someone else's work without proper citation"). However, many definitions contained more specific descriptors or clarifiers: "words, ideas, or concepts," "writing, thoughts, and ideas," "intellectual property," "information," "source material," "language, ideas, or other original material." Moreover, a significant number of definitions combined "work" with a more specific descriptor ("work and source material," "words/work," "work and pre-existing material," "work papers, reports, projects, etc."). One definition made an explicit distinction: "The practice of taking someone else's work or ideas and passing them off as [his/her] own."

Some respondents included a consideration of self-plagiarism in their definitions: "use of information without crediting the source, including self-plagiarism"; "active intent to use the words, opinions, and other written work... (and sometimes from the student's own prior paper)"; and "taking credit for work that isn't what you yourself did for that particular course." The faculty's comments in the Wordle cloud give greater prominence to words that appear more frequently in the source text as illustrated in figure 1.

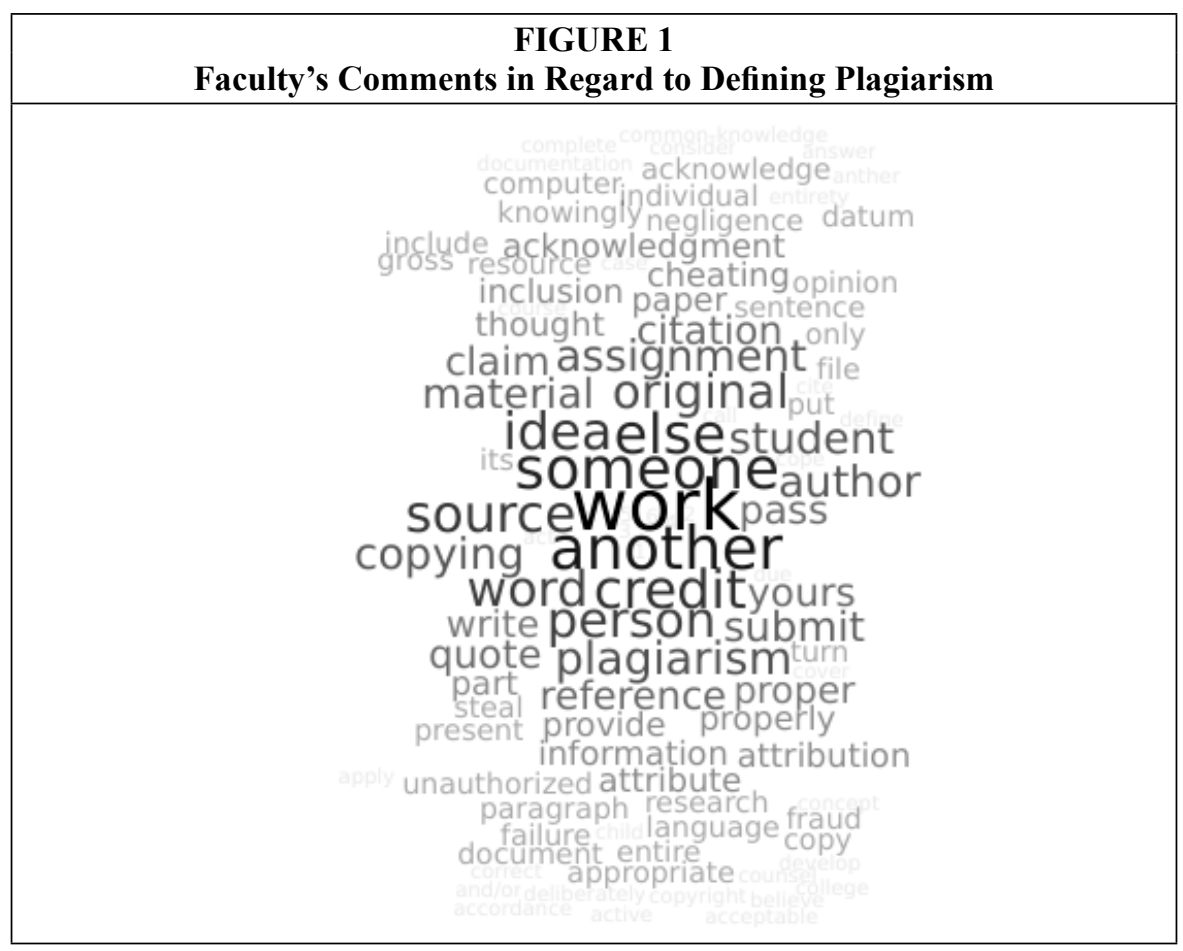


Ultimately, the researchers found the variations suggest that faculty have varying perceptions of:

$\square \quad$ the severity of plagiarism (such as whether it involves "using" the work of others as opposed to actually "stealing" it);

$\square \quad$ the level of knowledge students have (and thus, the level of detail needed) for them to understand what plagiarism is;

$\square \quad$ the necessity of explicitly stating that plagiarism involves a lack of source attribution or acknowledgment;

$\square \quad$ the role that intent plays in determining whether plagiarism has occurred.

\section{Faculty's Plagiarism Education Behaviors}

RQ2: How do faculty attempt to deter student plagiarism?

Faculty were asked questions related to teaching their students how to avoid plagiarism. They were asked to whether they incorporated comments about plagiarism in their syllabi, whether they spent time discussing plagiarism in their classes, and if they had invited a librarian to provide instruction on plagiarism concepts in any of their classes.

\section{Plagiarism Descriptions in Syllabi}

Faculty were nearly evenly divided in terms of whether they included a description of plagiarism in their syllabi, with 26 indicating that they do (55.3\%) and 21 indicating that they do not $(44.7 \%)$, as illustrated in table 5 .

\begin{tabular}{|c|c|c|c|c|c|c|c|c|c|c|}
\hline \multicolumn{10}{|c|}{ TABLE 5 } \\
\hline \multicolumn{10}{|c|}{ Do You Have a Description of Plagiarism in Your Syllabus? } \\
\hline & Faculty & Business Faculty & Arts Faculty & UG Faculty & GR Faculty \\
\hline & $\mathrm{N}=47$ & \multicolumn{2}{|c|}{$\mathrm{n}=31$} & \multicolumn{2}{|c|}{$\mathrm{n}=16$} & $\mathrm{n}=30$ & \multicolumn{2}{c|}{$\mathrm{n}=17$} \\
\hline & Yes & No & Yes & No & Yes & No & Yes & No & Yes & No \\
\hline $\mathrm{N}$ & 26 & 21 & 16 & 15 & 10 & 6 & 16 & 14 & 10 & 7 \\
\hline$\%$ & $55 \%$ & $45 \%$ & $52 \%$ & $48 \%$ & $62.5 \%$ & $37.5 \%$ & $53 \%$ & $47 \%$ & $59 \%$ & $41 \%$ \\
\hline
\end{tabular}

When comparing the academic departments of Business $(n=31)$ and Arts $(n=16)$, a higher percentage of the Arts Faculty stated that they included a description of plagiarism in their syllabi, 63 percent $(n=10)$ versus 52 percent $(n=16)$ of the Business Faculty. When comparing UG Faculty $(n=30)$ and GR Faculty $(n=17)$, more GR Faculty indicated that they included this description in their syllabi (59\%) versus UG Faculty (53\%).

\section{Use of Plagiarism Materials}

Faculty were nearly evenly divided in terms of whether they provided students with materials on plagiarism, with 47 percent $(n=22)$ stating Yes and 53 percent $(n=25)$ stating No, as illustrated in table 6 .

\begin{tabular}{|c|c|c|c|c|c|c|c|c|c|c|}
\hline \multicolumn{10}{|c|}{ TABLE 6 } \\
\hline \multicolumn{10}{|c|}{ Do You Provide Students with Materials on Plagiarism? } \\
\hline & Faculty & \multicolumn{2}{|c|}{ Business Faculty } & Arts Faculty & \multicolumn{2}{c|}{ UG Faculty } & \multicolumn{2}{c|}{ GR Faculty } \\
\hline & $\mathrm{N}=47$ & \multicolumn{2}{|c|}{$\mathrm{n}=31$} & \multicolumn{2}{c|}{$\mathrm{n}=16$} & $\mathrm{n}=30$ & \multicolumn{2}{c|}{$\mathrm{n}=17$} \\
\hline & Yes & No & Yes & No & Yes & No & Yes & No & Yes & No \\
\hline $\mathrm{n}$ & 22 & 25 & 16 & 15 & 10 & 6 & 14 & 16 & 8 & 9 \\
\hline$\%$ & $47 \%$ & $53 \%$ & $52 \%$ & $48 \%$ & $62.5 \%$ & $37.5 \%$ & $47 \%$ & $53 \%$ & $47 \%$ & $53 \%$ \\
\hline
\end{tabular}


When comparing the academic departments of Business $(n=31)$ and Arts $(n=16)$, a higher percentage of Arts Faculty $(63 \% ; n=10)$ indicated that they provided students with materials on plagiarism as compared to Business Faculty $(52 \% ; n=16)$. When comparing UG Faculty $(\mathrm{n}=30)$ and GR Faculty $(\mathrm{n}=17)$, slightly more GR Faculty indicated that they did so $(47 \% ; n=8)$ as compared to UG Faculty $(46 \% ; n=14)$.

RQ3: To what extent are library information literacy resources used to combat plagiarism?

\section{Use of Librarian Instruction}

Most faculty indicated that they have not had a librarian provide instruction on plagiarism concepts in any of their classes, with 26 percent stating Yes and 74 percent stating No, as illustrated in table 7.

\begin{tabular}{|c|c|c|c|}
\hline \multicolumn{10}{|c|}{ TABLE 7 } \\
Have You Ever Had a Librarian Provide Instruction on Plagiarism Concepts \\
in Any of Your Classes? \\
\hline \\
\hline
\end{tabular}

When comparing the academic departments of Business $(n=31)$ and Arts $(n=16)$, results were very similar, with 26 percent $(n=8)$ of the Business Faculty and 25 percent $(\mathrm{n}=4)$ of the Arts Faculty indicating that they did so. When comparing UG Faculty (n $=30)$ and GR Faculty $(n=17)$, slightly more UG Faculty $(27 \% ; n=8)$ as compared to GR Faculty $(24 \% ; n=4)$ claimed to have done so.

\section{Faculty Discussion of Plagiarism}

Faculty were asked if they personally discussed plagiarism in any of their classes. The majority of faculty indicated that they did $(87 \% ; n=41)$, as indicated in table 8 .

\begin{tabular}{|c|c|c|c|c|c|c|c|c|c|c|}
\hline \multicolumn{10}{|c|}{ TABLE 8 } \\
\hline \multicolumn{10}{|c|}{ Do You Personally Discuss Plagiarism in Any of Your Classes? } \\
\hline & Faculty & \multicolumn{2}{|c|}{ Business Faculty } & Arts Faculty & UG Faculty & GR Faculty \\
\hline & \multicolumn{2}{|c|}{$\mathrm{N}=47$} & \multicolumn{2}{|c|}{$\mathrm{n}=31$} & $\mathrm{n}=16$ & $\mathrm{n}=30$ & \multicolumn{2}{c|}{$\mathrm{n}=17$} \\
\hline & Yes & No & Yes & No & Yes & No & Yes & No & Yes & No \\
\hline $\mathrm{n}$ & 41 & 6 & 26 & 5 & 15 & 1 & 27 & 3 & 14 & 3 \\
\hline$\%$ & $87 \%$ & $13 \%$ & $84 \%$ & $16 \%$ & $94 \%$ & $6 \%$ & $90 \%$ & $10 \%$ & $82 \%$ & $18 \%$ \\
\hline
\end{tabular}

When comparing the academic departments of Business $(n=31)$ and Arts $(n=16)$, approximately 10 percent more of the Arts faculty indicated that they personally discussed plagiarism in their classes, with 94 percent $(n=15)$ indicating that they did versus the Business faculty with 84 percent $(n=26)$ stating that they did. When comparing UG faculty $(n=30)$ and GR faculty $(n=17)$, slightly more UG faculty indicated that they discussed plagiarism in their classes, 90 percent $(n=27)$ versus GR faculty at 82 percent $(n=14)$. 
Faculty who indicated that they personally discussed plagiarism in any of their classes $(n=41)$ were asked about the amount of time they spent doing so. Most faculty who indicated that they devoted time to discussing plagiarism in their classes stated that they spent $A$ little time doing so $(54 \% ; n=22)$. Across all faculty categories, on average, the largest number of respondents in each indicated that they spent $A$ little time doing so, as illustrated in table 9.

\begin{tabular}{|l|c|c|c|c|c|c|c|c|c|c|}
\hline \multicolumn{10}{|c|}{ TABLE 9 } \\
\hline & How Much Time Do You Devote to Discussing Plagiarism in Your Class? \\
\hline & \multicolumn{2}{|c|}{ Faculty } & \multicolumn{2}{c|}{$\begin{array}{c}\text { Business } \\
\text { Faculty }\end{array}$} & $\begin{array}{c}\text { Arts } \\
\text { Faculty }\end{array}$ & \multicolumn{2}{c|}{$\begin{array}{c}\text { UG } \\
\text { Faculty }\end{array}$} & \multicolumn{2}{c|}{$\begin{array}{c}\text { GR } \\
\text { Faculty }\end{array}$} \\
\hline & \multicolumn{2}{|c|}{$\mathrm{N}=41$} & \multicolumn{2}{c|}{$\mathrm{n}=26$} & \multicolumn{2}{c|}{$\mathrm{n}=15$} & \multicolumn{2}{c|}{$\mathrm{n}=30$} & \multicolumn{2}{c|}{$\mathrm{n}=17$} \\
\hline & $\#$ & $\%$ & $\#$ & $\%$ & $\#$ & $\%$ & $\#$ & $\%$ & $\#$ & $\%$ \\
\hline None at all & 0 & 0 & 0 & 0 & 0 & 0 & 0 & 0 & 0 & 0 \\
\hline A little & 22 & $54 \%$ & 14 & $54 \%$ & 8 & $53 \%$ & 14 & $47 \%$ & 8 & $47 \%$ \\
\hline A moderate amount & 15 & $37 \%$ & 8 & $31 \%$ & 7 & $47 \%$ & 13 & $43 \%$ & 2 & $12 \%$ \\
\hline A lot & 2 & $5 \%$ & 2 & $8 \%$ & 0 & $0 \%$ & 0 & $0 \%$ & 2 & $12 \%$ \\
\hline A great deal & 2 & $5 \%$ & 2 & $8 \%$ & 0 & $0 \%$ & 0 & $0 \%$ & 2 & $12 \%$ \\
\hline
\end{tabular}

\section{Discussion}

Faculty were asked to consider what behaviors constitute plagiarism. The researchers also asked faculty to explicitly define plagiarism, which the researchers believe was a unique addition to the library literature. As described previously, both for the faculty surveyed in this study and for those in other studies cited previously, the definition of plagiarism has fluctuated. The faculty surveyed in this study produced definitions that closely parallel this institution's definition of plagiarism as defined in the institution in this study's code of conduct:

The inclusion of another's words, ideas, or data as one's own work. This covers unpublished as well as published sources. Plagiarism includes, but is not limited to the following examples:

1. Quoting another person's words, sentences, paragraphs, or entire work without acknowledgment of the source.

2. Utilizing another person's ideas, opinions, or theory without acknowledgment of the source.

3. The use of resources without documentation on a task that is to be completed without resources.

4. Copying another student's essay test answer.

5. Copying, or allowing another student to copy, a computer file that contains another student's assignment, and submitting it, in part or in its entirety, as one's own.

6. Working together on an assignment, sharing the computer files and programs involved, and then submitting individual copies of the assignment as one's own individual work.

The researchers suggest that librarians acknowledge the multiple and in some cases conflicting definitions of plagiarism and discuss these multiple perspectives when collaborating with faculty. At the same time, the researchers propose that faculty elaborate on their own definitions by communicating - both to librarians and to students - their own perceptions of severity, by providing specific descriptions of the objects of plagia- 
rism (such as "words," "original ideas"), by specifically communicating the need for attribution and by communicating unintentional ways that students might plagiarize in their syllabus and course handouts.

During the extensive review of the literature, the research team regularly encountered articles that included commentary on behaviors related to educating students on not plagiarizing (in other words, if they included a description of plagiarism in their syllabus or devoted time to discussing it). The researchers learned that faculty were nearly evenly split in regard to including a description or discussing it with their students. Therefore, the researchers believe that librarians training students in regard to citing and the benefits of doing so would both be beneficial. This is supported by the Marcus and Beck study in which they concluded "since the faculty disagrees $50 \%$ of the time on what constitutes plagiarism, there is a need for workshops, tutorials and online instruction on the definition of plagiarism...."51

Similarly, the researchers learned that the vast majority of faculty (across all demographic groups), 74 percent $(\mathrm{n}=35)$, do not currently invite library staff into their classrooms to teach how to avoid plagiarism. Moreover, while 46.8 percent $(n=22)$ shared they gave handouts to students describing why students should not plagiarize in their research papers, 90.3 percent $(n=37)$ of the faculty (across all demographic groups) stated they spent little to a moderate amount of time discussing why students should not plagiarize in their classes. This suggests that library staff should market the library's information literacy program (ILA and SPIL-Q), including proper research methods that includes training students how to cite sources correctly, to all faculty, regardless of demographic group, who teach upper division and graduate-level courses at the college because of the increased emphasis on research at those levels.

\section{Conclusion}

The research team found a disparity between how plagiarism is defined and taught by faculty. As the researchers were unable to find other studies of library-led surveys attempting to gauge faculty's perceptions of student plagiarism, this work added to the literature in this space. Furthermore, this work examined to what extent faculty attempted to deter plagiaristic behaviors both personally and by using information literacy resources from the library. The researchers' review of faculty's plagiarism definitions (and their wide disparity) and discovery of faculty's limited use of library information literacy resources provided further evidence for the need to develop information literacy and plagiarism deterrent programs through librarian and faculty collaborations. Institutions should consider organizationwide efforts for these programs and how various academic and nonacademic departments could be leveraged. As a follow-up to this study, the research team is currently developing a series of antiplagiarism training modules for students, which will be deployed along with a survey of students' perceptions of their plagiaristic behaviors. Furthermore, the researchers plan to explore the potential intersection between students' plagiaristic perceptions and behaviors with their information literacy skills, based on the work previously published by Michalak and Rysavy as well as Michalak, Rysavy, and Wessel, and Rysavy, Michalak, and Hunt. ${ }^{52}$ 


\title{
Appendix. Faculty Perceptions of Student Plagiarism: Survey Flow
}

\author{
Block: Survey Consent (2 Questions) \\ Plagiarism (2 Questions) \\ Standard: Block 3 (3 Questions) \\ Standard: Block 4 (1 Question) \\ Standard: Block 5 (2 Questions) \\ Standard: Block 6 (2 Questions) \\ Standard: Block 7 (1 Question) \\ Standard: Block 8 (1 Question) \\ Standard: Block 9 (13 Questions)
}

Standard: Instructor Demographics (2 Questions)

Standard: Instructors' Perceptions of Domestic vs. International Students and

\section{Survey Consent}

Q1 You are being asked to participate in a research study about your perceptions of student plagiarism. Data collected in this survey may be shared with unidentifiable information-i.e. your name and identifying characteristics about you will not be shared-in articles, presentations, or public forums. Clicking on the "agree" button below indicates that you voluntarily agree to participate and that your data may be used in this manner. Clicking on the "disagree" button indicates that you are willing to complete the survey but do not wish for your unidentifiable responses to be included in articles, presentations, or public forums. Clicking on the final choice, "I do not wish to participate in this research study" will exclude you from participating in this study. All data will be utilized to improve teaching and learning at Goldey-Beacom College through the Office of Institutional Research \& Training. Thank you very much for your participation!

\section{Q2 Research Participation}

$\square \quad$ I agree to allow the use of my unidentifiable responses in articles, presentations, or public forums. (1)

$\square \quad$ I do not agree to allow the use of my unidentifiable responses in articles, presentations, or public forums. (2)

$\square \quad$ I do not wish to participate in this research study. (3)

Skip To: End of Survey If Q2 = I do not wish to participate in this research study. (3)

\section{Instructor Demographics}

Q3 Instructor Classification: Please select the instructor classification that you most identify with.

$\square \quad$ Full-time Faculty (1)

$\square \quad$ Adjunct Faculty (includes part-time faculty) (2)

Q4 Years Teaching: How many years have you taught at the College level?

$\square \quad$ Less than 1 year $(1)$

$1-5$ years $(2)$

6-10 Years (3)

․ More than 10 Years (4) 
Instructors' Perceptions of Domestic vs. International Students and Plagiarism Q5 Domestic Students and Plagiarism: Consider each statement and respond given your opinion regarding domestic students.

\begin{tabular}{|c|c|c|c|c|c|}
\hline & $\begin{array}{l}\text { Strongly } \\
\text { Agree } \\
\text { (1) }\end{array}$ & $\begin{array}{c}\text { Somewhat } \\
\text { Agree (2) }\end{array}$ & $\begin{array}{c}\text { Neither } \\
\text { Agree nor } \\
\text { Disagree (3) }\end{array}$ & $\begin{array}{l}\text { Somewhat } \\
\text { Disagree } \\
(4) \\
\end{array}$ & $\begin{array}{c}\text { Strongly } \\
\text { Disagree } \\
\text { (5) }\end{array}$ \\
\hline $\begin{array}{l}\text { The punishment for } \\
\text { plagiarism in college } \\
\text { should be light because } \\
\text { students are young people } \\
\text { just learning the ropes. (1) }\end{array}$ & 0 & 0 & 0 & 0 & 0 \\
\hline $\begin{array}{l}\text { It's okay for students to } \\
\text { use something they have } \\
\text { written in the past to } \\
\text { fulfill a new assignment } \\
\text { because you can't } \\
\text { plagiarize yourself. (2) }\end{array}$ & 0 & 0 & 0 & 0 & 0 \\
\hline $\begin{array}{l}\text { If a student caught } \\
\text { plagiarizing received a } \\
\text { special grade for cheating } \\
\text { (such as XF) on their } \\
\text { transcript, that policy } \\
\text { would deter plagiarizing. } \\
\text { (3) }\end{array}$ & 0 & 0 & 0 & 0 & 0 \\
\hline $\begin{array}{l}\text { If a student lends another } \\
\text { student a paper to look } \\
\text { at, and the second student } \\
\text { turns it in as his or her } \\
\text { own and is caught, the } \\
\text { original author of the } \\
\text { paper should not be } \\
\text { punished also. (4) }\end{array}$ & 0 & 0 & 0 & 0 & 0 \\
\hline $\begin{array}{l}\text { If a student buys or } \\
\text { downloads for free an } \\
\text { entire research paper and } \\
\text { turns it in unchanged } \\
\text { with his or her name as } \\
\text { author, the student should } \\
\text { be expelled from the } \\
\text { university. (5) }\end{array}$ & 0 & 0 & 0 & 0 & 0 \\
\hline $\begin{array}{l}\text { If a friend gives a student } \\
\text { permission to use his or } \\
\text { her paper for one of the } \\
\text { student's classes, there is } \\
\text { nothing wrong with it. (6) }\end{array}$ & 0 & 0 & 0 & 0 & 0 \\
\hline $\begin{array}{l}\text { Sometimes an individual } \\
\text { feels tempted to } \\
\text { plagiarize because so } \\
\text { many are doing it. (7) }\end{array}$ & 0 & 0 & 0 & 0 & 0 \\
\hline
\end{tabular}


Q6 International Students and Plagiarism: Consider each statement and respond given your opinion regarding international students.

\begin{tabular}{|c|c|c|c|c|c|}
\hline & $\begin{array}{l}\text { Strongly } \\
\text { agree } \\
\text { (1) } \\
\end{array}$ & $\begin{array}{c}\text { Somewhat } \\
\text { agree (2) }\end{array}$ & $\begin{array}{c}\text { Neither } \\
\text { agree nor } \\
\text { disagree (3) }\end{array}$ & $\begin{array}{l}\text { Somewhat } \\
\text { disagree } \\
(4) \\
\end{array}$ & $\begin{array}{l}\text { Strongly } \\
\text { disagree } \\
(5) \\
\end{array}$ \\
\hline $\begin{array}{l}\text { The punishment for } \\
\text { plagiarism in college } \\
\text { should be light because } \\
\text { students are young people } \\
\text { just learning the ropes. } \\
\text { (1) }\end{array}$ & 0 & 0 & 0 & 0 & 0 \\
\hline $\begin{array}{l}\text { It's okay for students to } \\
\text { use something they have } \\
\text { written in the past to } \\
\text { fulfill a new assignment } \\
\text { because you can't } \\
\text { plagiarize yourself. (2) }\end{array}$ & 0 & 0 & 0 & 0 & 0 \\
\hline $\begin{array}{l}\text { If a student caught } \\
\text { plagiarizing received a } \\
\text { special grade for cheating } \\
\text { (such as XF) on their } \\
\text { transcript, that policy } \\
\text { would deter plagiarizing. } \\
\text { (3) }\end{array}$ & 0 & 0 & 0 & 0 & 0 \\
\hline $\begin{array}{l}\text { If a student lends another } \\
\text { student a paper to look } \\
\text { at, and the second student } \\
\text { turns it in as his or her } \\
\text { own and is caught, the } \\
\text { original author of the } \\
\text { paper should not be } \\
\text { punished also. (4) }\end{array}$ & 0 & 0 & 0 & 0 & 0 \\
\hline $\begin{array}{l}\text { If a student buys or } \\
\text { downloads for free an } \\
\text { entire research paper and } \\
\text { turns it in unchanged } \\
\text { with his or her name as } \\
\text { author, the student should } \\
\text { be expelled from the } \\
\text { university. (5) }\end{array}$ & 0 & 0 & 0 & 0 & 0 \\
\hline $\begin{array}{l}\text { If a friend gives a student } \\
\text { permission to use his or } \\
\text { her paper for one of the } \\
\text { student's classes, there is } \\
\text { nothing wrong with it. (6) }\end{array}$ & 0 & 0 & 0 & 0 & 0 \\
\hline $\begin{array}{l}\text { Sometimes an individual } \\
\text { feels tempted to } \\
\text { plagiarize because so } \\
\text { many are doing it. (7) }\end{array}$ & 0 & 0 & 0 & 0 & 0 \\
\hline
\end{tabular}


Q7 How would you describe or define plagiarism?

Q8 Do you have a description of plagiarism in your syllabus?

$$
\begin{array}{ll}
\square \quad \text { Yes (1) } \\
\square \quad \text { No (2) }
\end{array}
$$

Q9 Do you provide students with materials on plagiarism?

$$
\begin{array}{ll}
\square \quad \text { Yes (1) } \\
\square \quad \text { No (2) }
\end{array}
$$

If Yes Is Selected:

Q10 What kinds of sources on plagiarism do you provide? Examples: Printed documents, web links, electronic documents, etc.

Q36 Have you ever had a librarian provide instruction on plagiarism concepts in any of your classes?

$$
\begin{array}{ll}
\square \quad \text { Yes (1) } \\
\square \quad \text { No (2) }
\end{array}
$$

Q11 Do you personally discuss plagiarism in any of your classes?

$\square \quad$ Yes (1)

$\square \quad$ No (2)

If Yes Is Selected:

Q12 How much time do you devote to discussing plagiarism in your class?

$\square \quad$ A great deal (1)

$\square \quad$ A lot (2)

$\square \quad$ A moderate amount (3)

$\square \quad$ A little (4)

$\square \quad$ None at all (5)

Q13 Why do you devote time to discussing plagiarism in your class?

Q14 During your time teaching at Goldey-Beacom College, have you ever filed academic honor code violation reports for instances of plagiarism in your classes?

$$
\begin{array}{ll}
\square \quad \text { Yes (1) } \\
\square \quad \text { No (2) }
\end{array}
$$

If Yes Is Selected:

Q15 Approximately how many honor code violation reports did you submit for instances of plagiarism in your classes during the 2015-2016 academic year?

$$
\begin{array}{ll}
\square & 0(1) \\
\square & 1-3(2) \\
\square & 4-6(3) \\
\square & 7-10(4) \\
\square & 10+(5)
\end{array}
$$

Q16 Approximately how many instances of student plagiarism did you encounter during the 2015-2016 academic year but did not file honor code violation reports?

$$
\begin{array}{ll}
\square & 0(1) \\
\square & 1-3(2) \\
\square & 4-6(3) \\
\square & 7-10(4) \\
\square & 10+(5)
\end{array}
$$


Q17 If plagiarism occurs in my class, I prefer to handle it on my own instead of submitting an official honor code violation report.

$\square \quad$ Strongly agree (1)

$\square \quad$ Somewhat agree (2)

$\square \quad$ Neither agree nor disagree (3)

$\square \quad$ Somewhat disagree (4)

$\square \quad$ Strongly disagree (5)

Q18 I don't report plagiarism because it is too difficult to prove.

$\square \quad$ Strongly agree (1)

$\square \quad$ Somewhat agree (2)

$\square \quad$ Neither agree nor disagree (3)

$\square \quad$ Somewhat disagree (4)

$\square \quad$ Strongly disagree (5)

Q19 I believe that plagiarism is a rising concern because it is increasing.

$\square \quad$ Strongly agree (1)

$\square \quad$ Somewhat agree (2)

$\square \quad$ Neither agree nor disagree (3)

$\square \quad$ Somewhat disagree (4)

$\square \quad$ Strongly disagree (5)

Q20 International students seem to plagiarize more frequently than domestic students.

$\square \quad$ Strongly agree (1)

$\square \quad$ Somewhat agree (2)

$\square \quad$ Neither agree nor disagree (3)

$\square \quad$ Somewhat disagree (4)

$\square \quad$ Strongly disagree (5)

Q21 I cut international students some slack when it comes to plagiarism because they often have different standards for plagiarism than the American education system.

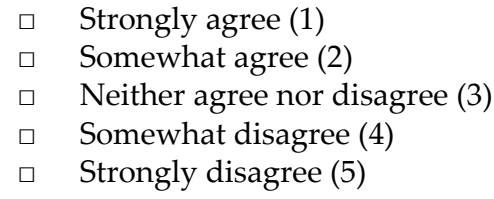

Q22 Please share any additional comments you'd like to add regarding international students and plagiarism here.

Q23 Plagiarism is against my ethical values.

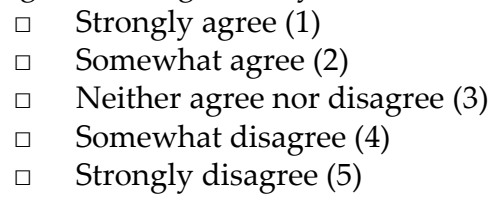

Q24 Plagiarism is not as bad as stealing the final exam ahead of time and memorizing the answers.
$\square \quad$ Strongly agree (1)
$\square \quad$ Somewhat agree (2) 
$\square \quad$ Neither agree nor disagree (3)

$\square \quad$ Somewhat disagree (4)

$\square \quad$ Strongly disagree (5)

Q25 I believe I know accurately what constitutes plagiarism and what does not.

$\begin{array}{ll}\square & \text { Strongly agree (1) } \\ \square & \text { Somewhat agree (2) } \\ \square & \text { Neither agree nor disagree (3) } \\ \square & \text { Somewhat disagree (4) } \\ \square & \text { Strongly disagree (5) }\end{array}$

Q26 Because plagiarism involves taking another person's words and not his or her material goods, plagiarism is no big deal.

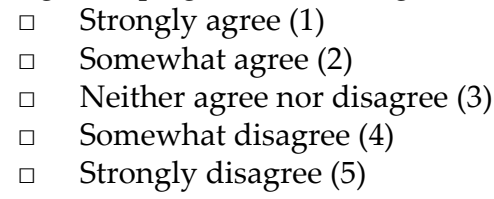

Q27 Plagiarism is justified if the student feels the professor assigned too much work.

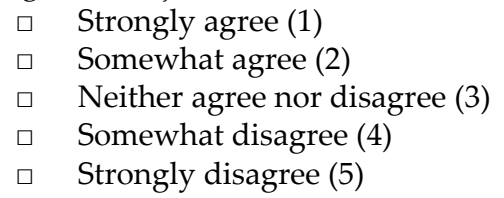

Q28 Sometimes an individual feels tempted to plagiarize because so many are doing it.

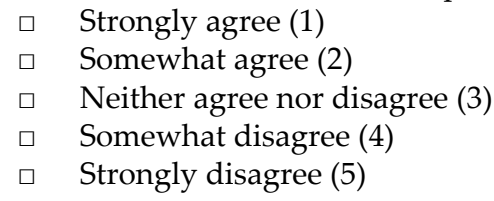

\section{Notes}

1. Robert A. Harris, The Plagiarism Handbook: Strategies for Preventing, Detecting, and Dealing With Plagiarism (Los Angeles: Pyrczak Publishing, 2001), 39.

2. Monica D.T. Rysavy, Russell Michalak, and Kevin Hunt, "Information Literacy Assessment for 1st-Year Composition Students: A Case Study of Three Deployment Modes," in Handbook of Research on Learner Experience and Usability in Online Education (Hershey, Pa.: IGI, 2018); Russell Michalak, Monica D.T. Rysavy, and Alison Wessel, "Students' Perceptions of Their Information Literacy Skills: The Confidence Gap Between Male and Female International Graduate Students," Journal of Academic Librarianship 42, no. 2 (2017): 100-04; Russell Michalak and Monica D.T. Rysavy, "Information Literacy in 2015: International Graduate Business Students' Perceptions of Information Literacy Skills Compared to Test-Assessed Skills," Journal of Business \& Finance Librarianship 21, no. 2 (2016): 152-74.

3. Rysavy, Michalak, and Hunt, "Information Literacy Assessment for 1st-Year Composition Students"; Michalak, Rysavy, and Wessel, "Students' Perceptions of Their Information Literacy Skills"; Michalak and Rysavy, "Information Literacy in 2015."

4. Harris, Plagiarism Handbook, 39.

5. Lynn D. Lampert, Combating Student Plagiarism (Oxford: Chandos Publishing, 2008), 42.

6. Jonathan Hall, "Plagiarism Across the Curriculum: How Academic Communities Can Meet the Challenge of the Undocumented Writer," Across the Disciplines 2, no. 9 (2005).

7. Lampert, Combating Student Plagiarism, 42.
} 
8. Susan Sciammarella, "Making a Difference: Library and Teaching Faculty Working Together to Develop Strategies in Dealing," Community \& Junior College Libraries 15, no. 1 (2009): 24.

9. Nancy S. Gibson and Christina Chester-Fangman, "The Librarian's Role in Combating Plagiarism," Reference Services Review 39, no. 1 (2011): 132-50.

10. Barbara Fister, "Common Ground: The Composition/Bibliographic Instruction Connection," in Academic Libraries: Achieving Excellence in Higher Education, ed. Thomas Kirk (Chicago: ACRL, 1992), 154-58.

11. Connie Strittmatter and Virginia K. Bratton, Teaching Plagiarism Prevention to College Students: An Ethics-Based Approach (Lanham, Md.: Rowman \& Littlefield, 2016), 9.

12. Dawn Amsberry, “Deconstructing Plagiarism: International Students and Textual Borrowing Practices," Reference Librarian 51, no. 1 (2009): 38.

13. Stephen Kiel, Natalie Burclaff, and Catherine Johnson, "Learning by Doing: A Baseline Information Literacy Assessment," Libraries and the Academy 15, no. 4 (2015): 747-66; Sarah Lowe, Char Booth, Natalie Tagge, and Sean Stone, "Impacting Information Literacy Learning in FirstYear Seminars: A Rubric-Based Evaluation," Libraries and the Academy 15, no. 3 (2014): 489-512; Ma Lei Hsieh, Patricia H. Dawson, Melissa A. Hofmann, Megan Titus, and Michael T. Carlin, Journal of Academic Librarianship 40, no. 3/4 (2014): 234-46; Margaret Fain, "Assessing Information Literacy: A Multi-Year Study," Journal of Academic Librarianship 37, no. 2 (2011): 109-19; Lampert, Combating Student Plagiarism; Mary Ann Trail, Carolyn Gutierrez, and David Lechner, "Reconsidering a Traditional Instruction Technique: Reassessing the Print Workbook," Journal of Academic Librarianship 32, no. 6 (2006): 632-40.

14. Michalak, Rysavy, and Wessel, "Students' Perceptions of Their Information Literacy Skills," 100-04; Michalak and Rysavy, "Information Literacy in 2015," 152-74; Susan Silver and Lisa Nickel, "Are Online Tutorials Effective? A Comparison of Online and Classroom Library Instruction Methods," Research Strategies 20, no. 4 (2007): 389-96; Douglas L. Cook, "Ship to Shore: An Online Information Literacy Tutorial Using BlackBoard Distance Education Software," Journal of Library Administration 37, no. 1/2 (2002): 177-87.

15. Michalak and Rysavy, "Information Literacy in 2015," 152-74. 18.

16. Shelley Angélil-Carter, Stolen Language? Plagiarism in Writing (London: Routledge, 2000),

17. Tilar J. Mazzeo, Plagiarism and Literary Property in the Romantic Period (Philadelphia: University of Pennsylvania Press, 2007), 2.

18. Ibid., 2.

19. Ibid., 2 .

20. Sue Carter Simmons, “Competing Notions of Authorship: A Historical Look at Students and

Textbooks on Plagiarism and Cheating," in Perspectives on Plagiarism an Intellectual Property in a Postmodern World (Albany: State University of New York Press, 1999), 42.

21. Ibid., 42.

22. Kymberley K. Bennett, Linda S. Behrendt, and Jennifer L. Boothby, "Instructor Perceptions of Plagiarism: Are We Finding Common Ground?" Teaching of Psychology 38, no. 1 (2011): 29.

23. Holly Seirup Pincus and Liora Pedhazur Schmelkin, "Faculty Perceptions of Academic Dishonesty: A Multidimensional Scaling Analysis," Journal of Higher Education 74, no. 2 (2003): 196.

24. Bennett, Behrendt, and Boothby, "Instructor Perceptions of Plagiarism," 29.

25. Angélil-Carter, Stolen Language? 15.

26. Scott Brandt, "Copyright's (Not So) Little Cousin, Plagiarism," Computers in Libraries 22, no. 5 (2002): 39-42; Rebecca Moore Howard, "Sexuality, Textuality: The Cultural Work of Plagiarism," College English 62, no. 4 (2002): 473-91; Stephen Wilhoit, "Helping Students Avoid Plagiarism," College Teaching 42, no. 4 (1994): 161-65.

27. Chris Park, "In Other (People's) Words: Plagiarism by University Students-Literature and Lessons," Assessment \& Evaluation in Higher Education 28, no. 5 (2003): 475.

25. Jude Carroll, A Handbook for Deterring Plagiarism in Higher Education (Oxford: Oxford

Centre for Staff and Learning Development, 2002), 9.

29. Diane Pecorari, "Good and Original: Plagiarism and Patchwriting in Academic Language Writing," Journal of Second Language Writing 12, no. 4 (2003): 318.

30. Pecorari, "Good and Original," 318; Jean Crocker and Philip Shaw, "Research Student and Supervisor Evaluation of Intertextuality Practices," Hermes Journal of Linguistics 28, no. 1 (2002): 39-58; Yu Ren Dong, "Non-native Graduate Students' Thesis/Dissertation Writing in Science: Self-Reports by Students and Their Advisors from Two U.S. Institutions," English for Specific Purposes 17, no. 4 (1998): 369-90; John Barker, "The Purpose of Study, Attitudes to Study and Staff-Student Relationships," in Overseas Students in Higher Education: Issues in Teaching and Learning, eds. D. McNamara and R. Harris (London: Routledge, 1997),108-23; Ruth Spack, "The 
Acquisition of Academic Literacy in a Second Language: A Longitudinal Case Study," Written Communication 14, no. 1 (1997): 3-62; Alastair Pennycook, "Borrowing Other's Words: Text, Ownership, Memory and Plagiarism," TESOL Quarterly 30, no. 2 (1996): 201-30; George Braine, "Writing in the Natural Sciences and Engineering," in Academic Writing in a Second Language: Essays on Research and Pedagogy, eds. D. Belcher and G. Braine (Norwood, N.J.: Ablex, 1995), 113-34; Ilona Leki, Understanding ESL Writers: A Guide for Teachers (Portsmouth, N.H.: Heinemann, 1992); Jane Sherman, "Your Thoughts in Your Own Words," ELT Journal 46, no. 2 (1992): 190-98; Philip Shaw, "Science Research Students' Composing Processes of Spanish for Specific Purposes," English for Specific Purposes 10, no. 3 (1991): 189-206; Maggie St. John, “Writing Processes of Spanish Scientists Publishing in English," English for Specific Purposes 6, no. 2 (1987): 113-20.

31. Sara Marcus and Sheila Beck, "Faculty Perceptions of Plagiarism at Queensborough Community College," Community $\mathcal{E}$ Junior College Libraries 17, no. 2 (2011): 64.

32. William J. Bowers, Student Dishonesty and Its Control in College (New York: Bureau of Applied Social Research, Columbia University, 1964), 64.

33. Ibid., 64.

34. Ibid., 221.

35. Tyler Evans-Tokyark, "Academic Integrity, Remix Culture, Globalization: A Canadian Case Study of Student and Faculty Perceptions of Plagiarism," Across the Disciplines: A Journal of Language, Learning, and Academic Writing 11 (2011): 4.

36. Bennett, Behrendt, and Boothby, "Instructor Perceptions of Plagiarism," 29.

37. Bill Marsh, Plagiarism: Alchemy and Remedy in Higher Education (Albany: State University of New York Press, 2007), 32.

38. Michael Price, "Beyond 'Gotcha!': Situating Plagiarism in Policy and Pedagogy," College Composition and Communication 54, no. 1 (2002): 88-115.

39. Bennett, Behrendt, and Boothby, "Instructor Perceptions of Plagiarism," 29; David A. Thomas, "How Educators Can More Effectively Understand and Combat the Plagiarism Epidemic," Brigham Young University Education and Law Journal 2 (2004): 421-30.

40. Michel Foucault, Power/Knowledge: Selected Interviews and Other Writings, 1972-1977 (trans. C. Gordon, L. Marshall, J. Mepham, and K. Soper), ed. C. Gordon (New York: Vintage Books, 1980), 52.

41. Christiane Donahue, "When Copying Is Not Copying: Plagiarism and French Composition Scholarship," in Originality, Imitation, and Plagiarism: Teaching Writing in the Digital Age, eds. C. Eisner and M. Vicinus (Ann Arbor: University of Michigan Press, 2008), 90-103; Celia Thompson and Alastair Pennycook, "Intertextuality in the Transcultural Contact Zone," in Pluralizing Plagiarism: Identities, Contexts, Pedagogies, eds. Rebecca Moore Howard and Amy E. Robillard (Portsmouth, N.H.: Boynton/Cook Publishers, 2008), 124-39.

42. Mikhail M. Bakhtin, "Discourse in the Novel," in The Dialogical Imagination: Four Essays (trans. C. Emerson and M. Holquist), ed. M. Holquist (Austin: University of Texas Press, 1981), 293.

43. Susan D. Blum, My Word! Plagiarism and College Culture (Ithaca, N.Y.: Cornell University Press, 2009), 30; Julia Kristeva, Desire in Language: A Semiotic Approach to Literature and Art (trans. Thomas Gora, Alice Jardine, and Leon S. Roudiez), ed. Leon S. Roudiez (New York: Columbia University Press, 1980 [1977]); Bakhtin, “Discourse in the Novel," 259-322.

44. Blum, My Word! Plagiarism and College Culture, 4.

45. Ibid., 5 .

46. Ibid., 5 .

47. Joel Bloch, Technologies in the Second Language Composition Classroom, The Michigan Series on Teaching Multilingual Writers (Ann Arbor: University of Michigan Press ELT, 2007), $228-29$.

48. Marcus and Beck, "Faculty Perceptions," 66.

49. Harris, Plagiarism Handbook, 39.

50. John W. Creswell, Quantitative Inquiry \& Research Design Choosing Among Five Approaches. Los Angeles: Sage Publications, 2013.

51. Marcus and Beck, "Faculty Perceptions of Plagiarism," 66.

52. Michalak and Rysavy, "Information Literacy in 2015," 152-74; Michalak, Rysavy, and Wessel, "Students' Perceptions of Their Information Literacy Skills," 100-04; Rysavy, Michalak, and Hunt, "Information Literacy Assessment for 1st-Year Composition Students." 